\title{
ASUPAN CAIRAN DAN STATUS HIDRASI MEMPENGARUHI PROFIL TEKANAN DARAH PADA ATLET SEPAKBOLA REMAJA
}

Fluid Intake and Hydration Status Influence Blood Pressure in Youth Football Athletes

\author{
Mirza Hapsari Sakti Titis Penggalih', Mohammad Juffrie ${ }^{2}$, Toto Sudargo ${ }^{3}$, \\ Zaenal Muttaqien Sofro ${ }^{4}$ \\ 1Program Doktor IImu Kedokteran dan Kesehatan; Bagian Gizi Kesehatan, \\ Fakultas Kedokteran, Universitas Gadjah Mada, Yogyakarta \\ 2Bagian IImu Kesehatan Anak, Fakultas Kedokteran, Universitas Gadjah Mada, Yogyakarta \\ ${ }^{3}$ Bagian Gizi Kesehatan, Fakultas Kedokteran, Universitas Gadjah Mada, Yogyakarta \\ ${ }^{4}$ Bagian Fisiologi, Fakultas Kedokteran, Universitas Gadjah Mada, Yogyakarta \\ E-mail: mirza.hapsari@ugm.ac.id
}

\section{ABSTRACT}

Athletes tend move with a higher intensity and longer than a normal healthy human being. High intensity exercise coupled with high environmental temperature leads to an increase in body temperature and increased risk of dehydration. Given that the negative impact of dehydration on cardiac function and termoregulatori at practice, then the fluid intake and hydration status were closely related to the stability of the heart to maintain the performance. The study was carried out in 4 months. It was an observational study with a longitudinal cohort design. The total subjects in this study were 131 teenage footballers. Statistical testing using multiple regression analysis. The study showed that fluid intake and hydration status, and change in body weight of the subjects before and after exercise provided significant effect on systolic blood pressure $(P<0.05)$. Every increased in fluid intake and changes in body weight lowers blood pressure by 0.408 systolic $\mathrm{mmHg}$, and increased in fluid intake and changes in percent body weight increase in blood pressure of $2.762 \mathrm{mmHg}$. The study concluded that intake of fluids as dehydration status protects athletes due to fluid loss. It was because the activities becomes an important key to reestablish the systolic blood pressure. The more frequent training, the more increasingly athletes being exposed to dehydration, so that the systolic blood pressure would continue to increase. It was recommended that rehydration for athletes - who experienced a weight loss of more than $2 \%$ - should be done immediately after exercise, asuming that $1 \mathrm{~kg}$ of body weigth loss could be replaced by at least 1 litter of fluid.

Keywords: fluid, hydration, systole, football, athlete

\section{ABSTRAK}

Atlet beraktivitas dengan intensitas lebih tinggi dan lebih lama daripada manusia sehat biasa. Intensitas latihan yang tinggi ditambah dengan suhu lingkungan yang tinggi mendorong terjadinya peningkatan suhu tubuh dan berisiko terhadap dehidrasi. Mengingat dampak negatif dehidrasi pada fungsi jantung dan termoregulatori saat latihan, maka asupan cairan dan status hidrasi erat hubungannya dengan kestabilan kerja jantung untuk menjaga performa. Penelitian ini bertujuan untuk mengetahui pengaruh asupan cairan dan status hidrasi atlet terhadap profil tekanan darah dan denyut jantung pada atlet. Penelitian ini merupakan penelitian observational dengan desain kohort longitudinal yang dilaksanakan selama 4 bulan. Total subyek yang ikut dalam penelitian ini sebanyak 131 atlet sepakbola remaja. Pengujian statistik menggunakan analisis regresi ganda. Hasil penelitian menunjukkan asupan cairan dan status hidrasi dengan pemantauan perubahan berat badan dan persen perubahan berat badan subyek saat sebelum dan sesudah latihan berpengaruh signifikan terhadap tekanan darah sistolik $(P<0.05)$. Arah hubungan tersebut adalah setiap kenaikan asupan cairan dan perubahan berat badan menurunkan tekanan darah sisitolik sebesar $0.408 \mathrm{mmHg}$, dan kenaikan asupan cairan serta perubahan persen berat badan menaikan tekanan darah sebesar $2.762 \mathrm{mmHg}$. Asupan cairan sebagai pengembali status dehidrasi atlet akibat aktivitasnya menjadi kunci penting untuk menstabilkan kembali tekanan darah sistolik. Semakin sering atlet latihan, semakin sering terpapar kondisi dehidrasi, maka tekanan darah sistolik atlet akan terus meningkat. Rehidrasi bagi atlet yang mengalami penurunan berat badan lebih dari 2 persen harus segera dilakukan pasca latihan, di mana kehilangan $1 \mathrm{~kg}$ berat badan dapat diganti dengan minimal $1 \mathrm{~L}$ cairan.

Kata kunci: cairan, hidrasi, sistol, sepakbola, atlet 


\section{PENDAHULUAN}

A tlet merupakan salah satu kelompok yang memiliki kebutuhan khusus yang harus diperhatikan. Atlet beraktivitas dengan intensitas lebih tinggi dan lebih lama daripada manusia sehat biasa. Intensitas latihan yang tinggi ditambah dengan suhu lingkungan yang tinggi mendorong terjadinya peningkatan suhu tubuh. ${ }^{1}$ Tubuh akan mengeluarkan keringat sebagai mekanisme penurunan suhu tubuh yang terus meningkat saat berolahraga. Mekanisme tubuh tersebut dapat memicu terjadinya kondisi dehidrasi.

Dehidrasi merupakan suatu kondisi tubuh yang kekurangan cairan atau keseimbangan cairan tubuh negatif. Keseimbangan cairan dipengaruhi dari cairan yang masuk dengan cairan tubuh yang terbuang. Kondisi keseimbangan cairan negatif terjadi ketika cairan tubuh yang terbuang lebih besar daripada cairan yang masuk ke dalam tubuh. Cairan tubuh dapat terbuang melalui keringat, urine, feses, proses respirasi, diare, serta muntah. $^{2}$ Asupan cairan yang tepat berdasarkan jenis serta jumlah merupakan langkah penting untuk mencegah dan/atau mengatasi dehidrasi, terutama bagi atlet.

Status hidrasi pada atlet dapat diketahui melalui berbagai macam parameter, antara lain perubahan berat badan sebelum dan sesudah latihan, pengukuran jumlah total cairan dalam tubuh, pengukuran jumlah asupan cairan, pengukuran indikator urine dan hematologi. Kehilangan lebih dari 2 persen berat badan pada saat latihan diketahui sebagai sebuah indikator terjadi dehidrasi karena pengeluaran cairan yang berlebih saat beraktivitas. Pengukuran dilakukan dengan penimbangan berat badan sebelum dan sesudah latihan. ${ }^{3}$ Jumlah total cairan dalam tubuh bisa diketahui dengan melakukan pengukuran menggunakan Bioelectrical Impedance Analysis (BIA). Indikator urine yang bisa dipakai untuk pengukuran status hidrasi antara lain warna, $\mathrm{pH}$ dan berat jenis urine. Apabila menggunakan aution stick maka pengukuran yang dilakukan termasuk kategori subyektif. ${ }^{3}$

Indikator hematologi yang umum digunakan yaitu perubahan hemoglobin dan hematokrit dalam darah ${ }^{4}$. Kondisi dehidrasi menunjukkan penurunan cairan dalam tubuh sehingga jumlah volume darah dan volume plasma juga turun.
Penurunan volume darah ini diketahui melalui penurunan konsentrasi hemoglobin dan hematokrit sesudah latihan. ${ }^{5}$ Penggunaan BIA dan hematologi belum bisa diterapkan pada penelitian ini dikarenakan kurang visible untuk dibawa ke lapangan, sehingga pengukuran status hidrasi dilakukan dengan perubahan berat badan, indikator warna urine dan pengukuran asupan cairan harian menggunakan semi quantitatif fluid frequency.

Beberapa studi mendapatkan bahwa rendahnya kesadaran atlet untuk mengonsumsi cairan secara cukup dan tepat, terutama setelah latihan, masih ditemukan, bahkan di tingkat profesional sekalipun. Penelitian yang dilakukan di Spanyol menemukan bahwa atlet-atlet sepakbola profesional tidak mengonsumsi cairan dalam jumlah yang cukup setelah latihan. ${ }^{6}$ Kondisi tidak menguntungkan setelah latihan atau kompetisi, seperti hiponatremia, hipoglikemia, hipokalemia hingga menyebabkan rasa mual, pusing, dan menurunnya konsentrasi, dilaporkan oleh beberapa hasil studi sebagai akibat dari dehidrasi. 7,8

Keseimbangan cairan dalam tubuh perlu diperhatikan, hal ini berkaitan dengan homeostasis cairan intraselluler maupun ekstraselluler untuk menjaga sel dalam kondisi normal. Asupan cairan yang berasal dari minuman harus seimbang dengan output cairan yang berasal dari invisible water loss (IWL) di kulit, keringat, feses dan urine. Kehilangan cairan melalui IWL diperkirakan 300-400 ml, melalui keringat pada suhu lingkungan yang normal berkisar $100 \mathrm{ml}$ sedangkan cairan yang dikeluarkan melalui feses $100 \mathrm{ml} /$ hari. Ekskresi cairan melalui urine dipengaruhi oleh berbagai macam faktor, pada kondisi normal (tidak dehidrasi, suhu lingkungan tidak terlalu dingin atau panas, dan tidak melakukan aktivitas berat) dalam sehari urine yang diproduksi yaitu $1400 \mathrm{ml}$ atau $1-2 \mathrm{ml} / \mathrm{kgBB} / \mathrm{jam} .{ }^{9}$

Kondisi dehidrasi dan melakukan aktivias yang berat mempengaruhi produksi urine, dalam satu hari jumlah urine pada keadaan ini bisa turun sampai $500 \mathrm{ml} / \mathrm{hari}$. Kondisi rehidrasi yang berlebihan, menyebabkan jumlah cairan lebih banyak dan untuk menyeimbangkan ekskresi urine bisa lebih banyak dari 2 $\mathrm{ml} / \mathrm{kgBB} / \mathrm{jam}$. Volume urine yang dapat ditampung pada kandung kemih yaitu $400 \mathrm{ml}$, ketika kandung kemih mencapai volume ini maka saraf-saraf yang ada pada dinding 
kandung kemih meningkat sehingga menyebabkan kontraksi dan keinginan untuk buang air kecil. 9

Asupan cairan atlet yang inadekuat dapat disebabkan oleh kebiasaan atlet untuk mengonsumsi cairan hanya berdasarkan rasa haus. Rasa haus merupakan reflek tubuh yang muncul ketika tubuh kehilangan cairan sebesar 2 persen dan atlet sangat mungkin dapat kehilangan cairan melebihi dari angka tersebut. ${ }^{10}$ Kecenderungan atlet untuk mengabaikan kebutuhan cairan tersebut disebut sebagai voluntary dehydration. Atlet sepakbola merupakan salah satu atlet yang paling berisiko untuk mengalami kondisi tersebut. $11,12,13$

Sepakbola merupakan jenis olahraga dengan intensitas tinggi sekaligus intermittent. Selain itu, durasi pertandingan yang cukup panjang dan mengharuskan pemain untuk selalu berkonsentrasi penuh sepanjang pertandingan sehingga pemain sepakbola cenderung kesulitan untuk minum dan menjaga status hidrasinya. ${ }^{14}$ Respon fisiologis yang sering dipengaruhi oleh aktivitas tersebut adalah denyut jantung dan tekanan darah. Denyut jantung ditentukan oleh intensitas latihan relatif yang diekspresikan dalam kapasitas aerobik maksimal (VO2 maks).

Kenaikan denyut jantung yang progresif dapat dikaitkan dengan kenaikan panas saat latihan. Peningkatan cardiac output ditujukan untuk memenuhi kebutuhan aliran darah pada permukaan kulit sebagai kompensasi dari heat loss. Secara keseluruhan, ketika dehidrasi terjadi, diperlukan peningkatan denyut jantung sebagai kompensasi penurunan stroke volume akibat penurunan pengembalian darah ke jantung. Apabila hal tersebut tidak dipenuhi, maka peningkatan level dehidrasi dan hipertermia akan terjadi. Mengingat dampak negatif dehidrasi pada fungsi jantung dan termoregulatori saat latihan. Pemulihan hingga euhidrasi memberikan prospek peningkatan performa dan kontrol homeostatis yang lebih baik. Konsumsi cairan selama latihan dapat secara efektif mengganti sweat loss dan memasok substrat bahan bakar. ${ }^{15}$

Permasalahan klinis yang dialami atlet sangat erat hubungannya dengan keadaan tekanan darah dan denyut jantung. Denyut jantung pada atlet saat isitrahat cenderung lebih rendah dari orang normal, yaitu berkisar 48-52 denyut per menit yang berarti atlet dalam kondisi sangat terlatih. ${ }^{16}$ Kondisi ini diikuti dengan rendahnya tekanan darah diastol yakni $70 \mathrm{mmHg}$. Denyut jantung yang sedikit melambat membuat atlet dalam keadaan relaks lebih lama. Namun demikian, hasil pemeriksaan denyut jantung atlet sepak bola di Indonesia menunjukkan bahwa hampir semua atlet memiliki denyut jantung lebih dari 60 kali per menit, sedangkan tekanan darah sistol di atas $110 \mathrm{mmHg}$ dan tekanan darah diastol antara 60-80 mmHg. Keadaan ini banyak diakibatkan karena pola tidur yang tidak baik, dehidrasi, kelelahan, recovery yang kurang memadai pada atlet meskipun mereka sudah diasramakan. ${ }^{17}$ Kondisi jantung yang tidak optimal sangat mempengaruhi performa atlet.

Oleh karena itu diperlukan pengkajian mengenai studi hubungan tentang pola asupan cairan dan status hidrasi atlet terhadap tekanan darah dan denyut jantung atlet. Manfaat dari penelitian ini adalah dapat memberikan informasi kepada atlet untuk selalu menjaga kesimbangan cairannya agar tidak terjadi peningkatan tekanan darah yang terus menerus akibat dehidrasi.

\section{METODE PENELITIAN}

\section{Desain Penelitian}

Penelitian ini merupakan penelitian observasional dengan desain kohor longitudinal. Subyek diamati dalam periode waktu 4 bulan untuk diamati pola asupan cairan, status hidrasi, berat badan, tekanan darah dan nadi sebelum dan sesudah latihan.

\section{Populasi dan Sampel}

Penelitian dilaksanakan di Asrama Atlet Remaja Ragunan, Kemenpora RI Jakarta dan Sekolah Sepak Bola Aji Santoso International Football Academy (SSB ASIFA) pada bulan Januari sampai dengan Juni 2016. Populasi target adalah atlet sepakbola laki-laki dan populasi terjangkau pada penelitian ini adalah atlet sepakbola remaja. Kriteria dalam penelitian ini adalah atlet sepak bola remaja, aktif berlatih, berusia 12-19 tahun dan bersedia mengikuti penelitian dengan menandatangani informed consent. Populasi penelitian ini sebanyak 145 orang atlet sepakbola di ASIFA Malang dan 26 orang atlet sepakbola di asrama atlet Ragunan. Semua populasi penelitian diikutkan dalam penelitian. Adapun kriteria eksklusi meliputi atlet 
cedera saat dilakukan penelitian. Total subyek yang ikut sampai akhir penelitian ini sebanyak 131 atlet sepakbola remaja.

\section{Proses Pengumpulan Data}

Penelitian ini diawali dengan melakukan penjelasan penelitian dan penandatanganan informed consent subyek penelitian. Kemudian dilakukan pendampingan subyek setiap hari untuk mengambil data asupan cairan setelah latihan dan asupan cairan mingguan, pemantauan tekanan darah dan berat badan setiap hari sebelum dan sesudah latihan dan pemeriksaan profil urine setiap 1 bulan sekali. Monitoring asupan cairan dengan melakukan dua pendekatan, yaitu mencatat jenis dan jumlah yang diminum subyek selama latihan dengan fluid record dan melakukan wawancara asupan cairan menggunakan kuesioner semi kuantitatif fluid frekuensi setiap 2 minggu sekali. Monitoring tekanan darah dan berat badan terus dipantau setiap hari saat sebelum dan sesudah latihan selama 4 bulan. Seluruh data disajikan dalam bentuk rata-rata selama empat bulan dan dilakukan analisis data lebih lanjut.

\section{Teknik Analisis Data}

Analisis univariat digunakan untuk mendeskripsikan setiap variabel yang diteliti dalam penelitian yaitu dengan melihat distribusi frekuensi variabel terikat (tekanan darah dan denyut jantung) serta variabel bebas (asupan cairan dan status hidrasi). Data tersebut dianalisis menggunakan software yang meliputi mean, median, standar deviasi, minimummaksimum, frekuensi, persentase dan uji normalitas data. Pada uji normalitas menggunakan uji Kolmogorov-smirnov apabila $p<0,05$ berarti variabel mempunyai distribusi tidak normal. Selanjutnya dilakukan analisis bivariat ini digunakan untuk melihat hubungan antara asupan cairan dan status hidrasi terhadap tekanan darah dan denyut jantung menggunakan analisis regresi ganda.

\section{HASIL}

\section{Karakteristik Subyek Penelitian}

Karakteristik berdasarkan sosiodemografi (Tabel 1) menunjukkan bahwa 73,3 persen berasal dari suku Jawa diikuti oleh suku-suku lain di Indonesia. Sebaran usia terbanyak adalah 12-15 tahun $(68,7 \%)$ dan mayoritas beragama Islam $(95,4 \%)$. Sebagian besar telah bergabung dengan tim selama 4 tahun $(73,3 \%)$ dan sebagian besar mengikuti kompetisi 2 hingga 3 kali $(48,1 \%)$ dan baru tergabung dalam satu klub saja $(63,4 \%)$.

Karakteristik berdasarkan riwayat kesehatan dan kebiasaan subyek (Tabel 2) menunjukkan bahwa sebagian besar tidak mengalami alergi (89,3\%), tidak merokok $(92,4 \%)$, tidak mengonsumsi alkohol $(90,1)$, mengonsumsi kafein $(90,08)$, tidak menggunakan suplemen $(66,4 \%)$, meskipun masih ada beberapa yang mengalami alergi, merokok, minum alkohol, tidak minum kopi dan menggunakan suplemen. Selain itu kebiasaan tidur sebagian besar subyek adalah 6-8 jam perhari $(78,6 \%)$ dan $3-4$ jam sekolah $(66,4 \%)$.

\section{Gambaran Asupan Cairan, Status Hidrasi, Tekanan Darah dan Nadi Subyek Penelitian}

Hasil pengukuran total asupan cairan, indikator status hidrasi, tekanan darah, dan nadi dari pre assessment sampai pengamatan bulan ke-3 disajikan dalam Tabel 3. Berdasarkan tabel tersebut, total asupan cairan mengalami penurunan dari pre hingga bulan ke-3. Perubahan hasil pemeriksaan warna urine dan berat jenis urine tidak menunjukkan perbedaan yang signifikan. Pada bulan ke-3 pengamatan, terdapat penurunan nilai selisih berat badan. Hal tersebut menunjukkan bahwa ditinjau dari perubahan berat badan, status hidrasi pada pengamatan bulan terakhir membaik dibandingkan dengan bulan sebelumnya. Tekanan darah dan denyut jantung mengalami peningkatan pada pengamatan bulan terakhir meskipun tidak menunjukkan hasil yang signifikan.

\section{Hubungan antara Status Hidrasi dengan Tekanan Darah dan Denyut Jantung}

Hubungan variabel ini ditentukan dengan pendekatan regresi logistik. Analisis hubungan ini diawali dengan menentukan model fit dan layak untuk diinterpetasikan menggunakan 2Log Likelihood. Model dinyatakan layak apabila nilai tersebut di bawah Chi-Square Table dengan df $(n-1)=131-1=130$ dan signifikansi 0,05 adalah 157,61. Pada Tabel 4 model yang dinyatakan layak adalah hubungan antara warna urine, berat jenis urine, delta berat badan dan persen perubahan berat badan 
terhadap tekanan darah diastol dan denyut jantung.

Berdasarkan hasil uji Nagelkerke RSquare, dapat disimpulkan bahwa warna urine mempengaruhi 5,7 persen tekanan darah diastolik dan 4,1 persen denyut jantung. Berat jenis mempengaruhi 23,0 persen diastol dan 3,4 persen denyut jantung. Perubahan berat badan latihan mempengaruhi 5,5 persen diastol dan 2,1 persen denyut jantung. Pada persen perubahan berat badan latihan mempengaruhi
1,4 persen diastol dan 3,6 persen denyut jantung. Rata-rata variabel tersebut mempengaruhi tidak lebih dari 6 persen terhadap diastol dan denyut jantung, sehingga 94,0 persen dipengaruhi oleh faktor lain. Sementara untuk berat jenis urine terhadap diastol, 77,0 persen dipengaruhi oleh faktor lain. Analisis dengan menyertakan faktor lain perlu dilakukan untuk menegaskan faktor yang mempengaruhi perubahan tekanan darah dan denyut jantung seperti pada Tabel 5 .

Tabel 1

Karakteristik Sosiodemografi Subyek Penelitian

\begin{tabular}{|c|c|c|}
\hline Keterangan & $n$ & $\%$ \\
\hline \multicolumn{3}{|l|}{ Asal/Suku } \\
\hline - Jawa & 96 & 73,3 \\
\hline - Sumatera & 11 & 8,4 \\
\hline - Kalimantan & 9 & 6,9 \\
\hline - Sulawesi & 7 & 5,3 \\
\hline - Papua & 1 & 0,8 \\
\hline - NTB/NTT & 2 & 1,5 \\
\hline - Bali & 5 & 3,8 \\
\hline \multicolumn{3}{|l|}{ Umur } \\
\hline - $\quad$ 12-15 Tahun & 90 & 68,7 \\
\hline - $\quad 15-19$ Tahun & 41 & 31,3 \\
\hline \multicolumn{3}{|l|}{ Agama } \\
\hline - Islam & 125 & 95,4 \\
\hline - Hindhu & 2 & 1,5 \\
\hline - Budha & 1 & 0,8 \\
\hline - Kristen & 3 & 2,3 \\
\hline \multicolumn{3}{|c|}{ Lama bergabung dengan tim (Tahun) } \\
\hline$-0-4$ & 96 & 73,3 \\
\hline$-5-8$ & 24 & 18,3 \\
\hline$-9-12$ & 11 & 8,4 \\
\hline \multicolumn{3}{|l|}{ Durasi mengikuti kompetisi } \\
\hline$-0-1$ & 34 & 25,9 \\
\hline$-\quad 2-3$ & 63 & 48,1 \\
\hline-4 & 34 & 26.0 \\
\hline \multicolumn{3}{|l|}{ Jumlah klub yang pernah diikuti } \\
\hline$-0-1$ & 83 & 63,4 \\
\hline$-\quad 2-3$ & 43 & 32,8 \\
\hline$-\quad 4-5$ & 5 & 3,8 \\
\hline Total & 131 & 100,0 \\
\hline
\end{tabular}


Tabel 2

Karakteristik Riwayat Kesehatan dan Kebiasaan Subyek Penelitian

\begin{tabular}{ccc}
\hline Keterangan & $\mathrm{n}$ & $\%$ \\
\hline Alergi & 14 & 10,7 \\
$-\quad$ Ya & 117 & 89,3 \\
$-\quad$ Tidak & & \\
Kebiasaan Merokok & 10 & 7,6 \\
$-\quad$ Ya & 121 & 92,4 \\
$-\quad$ Tidak & & \\
Kebiasaan Alkohol & 13 & 9,9 \\
$-\quad$ Ya & 118 & 90,1 \\
$-\quad$ Tidak & & \\
Kebiasaan Kafein & 118 & 90,08 \\
$-\quad$ Ya & 13 & 9,92 \\
$-\quad$ Tidak & & \\
Penggunaan Suplemen & 44 & 33,6 \\
$-\quad$ Ya & 87 & 66,4 \\
$-\quad$ Tidak & & \\
Kebiasaan Tidur & 103 & 78,6 \\
$-\quad 6-8$ & 22 & 16,8 \\
$-\quad 8,5-10$ & 6 & 4,6 \\
$-\quad>10$ & & \\
Jam Sekolah & 87 & 66,4 \\
$-\quad 3-4$ & 43 & 32,8 \\
$-\quad 4,5-5$ & 1 & 0,8 \\
\hline$\quad>5$ & 131 & 100,0 \\
\hline Total & & \\
\hline
\end{tabular}

Tabel 3

Perubahan Hasil Pemeriksaan Subyek Penelitian

\begin{tabular}{lccccc}
\hline Variabel & Pre & B-1 & B-2 & B-3 & Rata-Rata \\
\hline Total Asupan Cairan & 2796,8 & 2606,3 & 2544,1 & 2458,4 & 2601,4 \\
Warna Urine & 4,27 & 4,73 & 3,95 & 4,19 & 4,29 \\
Berat Jenis Urine & 1,025 & 1,028 & 1,026 & 1,027 & 1,026 \\
Delta Berat Badan & - & $-0,37$ & $-0,64$ & $-0,29$ & $-0,43$ \\
Persen Perubahan Berat Badan & - & $-0,66$ & $-1,06$ & $-0,49$ & $-0,74$ \\
Sistol & 121,1 & 120,6 & 123,3 & 122,4 & 121,8 \\
Diastol & 69,5 & 68,0 & 70,9 & 70,7 & 69,8 \\
Denyut Jantung & 69,8 & 75,2 & 76,9 & 77,0 & 74,7 \\
\hline
\end{tabular}

Hubungan Asupan Cairan dan Status Hidrasi terhadap Tekanan Darah dan Denyut Jantung

Analisis regresi logistik dengan melibatkan faktor lain yang diasumsikan dapat mempengaruhi status hidrasi yaitu asupan cairan dapat dilihat pada Tabel 5. Model terbaik adalah asupan cairan dan status hidrasi dengan indikator perubahan berat badan dan persen perubahan berat badan berhubungan erat dengan tekanan darah sistol. Arah hubungan tersebut adalah setiap kenaikan asupan cairan dan perubahan berat badan menurunkan tekanan darah sistol sebesar $0,408 \mathrm{mmHg}$. Setiap kenaikan asupan cairan dan perubahan persen berat badan menaikkan tekanan darah sebesar 2,762 $\mathrm{mmHg}$. 
Tabel 4

Penentuan Model Hubungan dan Besarnya Pengaruh Independen Variabel terhadap Tekanan Darah dan Denyut Jantung

\begin{tabular}{llccc}
\hline Independen Variabel & Dependen Variabel & $\begin{array}{c}-2 \text { Log } \\
\text { likelihood }\end{array}$ & Cox \& Snell R Square & $\begin{array}{c}\text { Nagelkerke R } \\
\text { Square }\end{array}$ \\
\hline Warna Urine & Sistol & $179,889^{*}$ & 0,003 & 0,004 \\
& Diastol & 62,579 & 0,023 & 0,057 \\
& Denyut Jantung & 52,765 & 0,014 & 0,041 \\
\hline Berat Jenis & Sistol & $179,937^{*}$ & 0,003 & 0,004 \\
& Diastol & 64,378 & 0,009 & 0,230 \\
& Denyut Jantung & 53,098 & 0,012 & 0,034 \\
\hline Delta Berat Badan & Sistol & $169,857^{*}$ & 0,077 & 0,103 \\
& Diastol & 62,725 & 0,021 & 0,055 \\
& Denyut Jantung & 53,694 & 0,007 & 0,021 \\
\hline Persen Delta Berat Badan & Sistol & $171,463^{*}$ & 0,065 & 0,087 \\
& Diastol & 64,865 & 0,005 & 0,014 \\
& Denyut Jantung & 53,029 & 0,012 & 0,036 \\
\hline
\end{tabular}

Tabel 5

Analisis Regresi Logistik Asupan Cairan dan Status Hidrasi terhadap Variabel Dependen

\begin{tabular}{llcccc}
\hline Independen Variabel & Dependen Variabel & B & Standar Error & Exp $(\mathrm{B})$ & $\mathrm{p}$ \\
\hline Total Cairan & 1. Sistol & $-0,165$ & 1,429 & 0,847 & 0,908 \\
Warna Urine & & 0,235 & 0,370 & 1,265 & 0,525 \\
& 2. Diastol & $-18,389$ & 0,2760 & 0,000 & 0,999 \\
& & 1,497 & 1,078 & 4,468 & 0,165 \\
& 3. Denyut Jantung & $-18,489$ & 0,2800 & 0,000 & 0,999 \\
& & $-1,006$ & 0,788 & 0,366 & 0,202 \\
\hline Total Cairan & 1. Sistol & $-0,232$ & 1,428 & 0,793 & 0,871 \\
Berat Jenis & & $-0,218$ & 0,366 & 0,804 & 0,552 \\
& 2. Diastol & $-18,551$ & 0,2818 & 0,000 & 0,999 \\
& & 0,742 & 0,824 & 2,100 & 0,368 \\
& 3. Denyut Jantung & $-18,453$ & 0,2808 & 0,000 & 0,999 \\
& & $-0,896$ & 0,787 & 0,408 & 0,255 \\
\hline Total Cairan & 1. Sistol & 0,000 & 0,000 & 1,000 & 0,145 \\
Delta Berat Badan & & $-0,896$ & 0,268 & 0,408 & $0,015^{*}$ \\
& 2. Diastol & 0,000 & 0,000 & 1,000 & 0,461 \\
& & $-0,498$ & 0,302 & 0,608 & 0,099 \\
& 3. Denyut Jantung & 0,000 & 0,001 & 1,000 & 0,370 \\
& & $-0,079$ & 0,438 & 0,857 & 0,924 \\
\hline Total Cairan & 1. Sistol & 0,000 & 0,000 & 1,000 & 0,046 \\
Persen Berat Badan & & 1,016 & 0,395 & 2,762 & $0,010^{*}$ \\
& 2. Diastol & 0,000 & 0,000 & 1,000 & 0,438 \\
& & 0,408 & 0,737 & 1,503 & 0,580 \\
& 3. Denyut Jantung & 0,000 & 0,001 & 0,999 & 0,294 \\
& & $-0,704$ & 0,875 & 0,494 & 0,421 \\
\hline & & & &
\end{tabular}




\section{BAHASAN}

Status hidrasi perlu diperhatikan karena dapat mempengaruhi sitem fisiologis yang terjadi di dalam tubuh manusia. Atlet merupakan kelompok yang berisiko untuk mengalami dehidrasi. Pada atlet sepak bola, kehilangan 2 persen massa tubuhnya akan menurunkan performa. ${ }^{18}$ Warna urine, berat jenis urine, dan persen perubahan berat badan merupakan indikator status hidrasi. Studi pada 107 atlet sepak bola selama berada di kamp pelatihan menunjukkan bahwa 89 persen atlet mengalami dehidrasi, ditunjukkan dengan berat jenis urine pagi $>1,020 \mathrm{~g} / \mathrm{ml}$. Setelah melakukan latihan, 96 persen mengalami dehidrasi. ${ }^{19}$ Studi lainnya menunjukkan atlet sepakbola remaja yang mengalami dehidrasi setelah latihan mencapai 89,6 persen, masih menunjukkan angka yang tinggi. ${ }^{20}$

Studi yang dilakukan di Afrika Selatan menunjukkan bahwa sebagian besar atlet mengalami dehidrasi sebelum dan sesudah latihan dilihat dari berat jenis urine dan hanya sedikit yang terhidrasi baik (5\% sebelum latihan dan $1 \%$ setelah latihan). ${ }^{21}$ Warna urine sebagai indikator status hidrasi adalah jumlah urokrom dari hasil pemecahan hemoglobin. ${ }^{22}$ Pengamatan terhadap warna urine atlet menunjukkan bahwa urine atlet berwarna gelap setalah latihan. ${ }^{23} \mathrm{Hal}$ tersebut mengindikasikan bahwa latihan mengakibatkan peningkatan pemecahan hemoglobin sehingga urokrom terbentuk lebih banyak dan warna urine menjadi lebih gelap.

Status hidrasi mempengaruhi heart rate variability (HRV). Atlet yang dehidrasi akan mengalami penurunan HRV, di mana hal tersebut dapat menurunkan aktivitas parasympathetic dan meningkatkan aktivitas sympathetic ataupun keduanya. Saraf sympathetic berfungsi untuk meningkatkan denyut jantung. Sebaliknya, parasympathetic berfungsi untuk menurunkan denyut jantung. Aktivitas sympathetic pada atlet yang dehidrasi akan meningkat sehingga mengakibatkan denyut jantung atlet meningkat. Aktivitas parasympathetic atlet yang menurun akibat dehidrasi juga mengakibatkan denyut jantung atlet menjadi meningkat. ${ }^{24}$

Atlet yang mengalami dehidrasi melebihi 35 persen akan mengalami heat stress. Volume plasma menurun akan mengakibatkan peningkatan denyut jantung submaksimal dan penurunan cardiac output. Hal tersebut akan menimbulkan darah yang mengalir berkurang sehingga zat gizi yang seharusnya diedarkan oleh darah berkurang dan dapat menyebabkan perubahan metabolisme seluler. ${ }^{25,3} \mathrm{Hal}$ tersebut berisiko menimbulkan menurunnya performa.

Orang yang berolahraga akan mengeluarkan keringat yang berlebih dan suhu tubuh meningkat. Kelebihan pengeluaran keringat tersebut akan meningkatkan osmolalitas plasma dan kepadatan volume plasma sehingga meningkatkan tekanan darah serta denyut jantung. ${ }^{26}$ Olahraga juga menyebabkan konsumsi oksigen menurun. Tubuh akan merespon hal tersebut dengan cara meningkatkan kerja jantung agar darah dapat menyuplai oksigen ke seluruh tubuh sehingga denyut jantung akan meningkat. ${ }^{27}$

Perubahan berat badan atlet yang diukur sebelum dan sesudah latihan dapat dijadikan sebagai indikator status hidrasi. Hal tersebut menunjukkan seberapa besar atlet kehilangan cairan. Atlet yang kurang mengonsumsi cairan ditambah dengan latihan pada suhu yang tinggi cenderung mengalami dehidrasi baik sebelum maupun sesudah latihan, ditunjukkan dengan persen kehilangan berat badan hingga 1 persen. ${ }^{21}$

Penggantian cairan untuk atlet setelah berolah raga sangat diperlukan agar terhindar dari status dehidrasi. Adanya peningkatan suhu tubuh $0,15-0,20^{\circ} \mathrm{C}$ saat berolahraga dapat meningkatkan 1 persen kehilangan berat badan dari keringat yang keluar. ${ }^{28,29}$ Kehilangan berat badan sebesar $1 \mathrm{~kg}$ dapat diasumsikan sebagai kehilangan cairan tubuh sebesar 1 L. ${ }^{30,31} \mathrm{Hal}$ ini mempengaruhi respon kardiovaskular yang ditandai oleh peningkatan denyut jantung, penurunan stroke volume, dan peningkatan systemic vascular resistance. ${ }^{32}$ Setiap kehilangan 1 persen berat badan, denyut jantung dapat meningkat 5-8 denyut per menit. ${ }^{33}$ Oleh karena itu, diperlukan rehidrasi yang cukup untuk menggantikan cairan tubuh yang hilang akibat dehidrasi.

Pengukuran cairan tubuh yang hilang dan asupan cairan pada atlet sepak bola remaja di Brazil saat pertandingan tidak menunjukkan adanya hubungan. Namun, atlet yang hanya menggantikan kehilangan cairan tubuhnya sebanyak 50 persen mengalami dehidrasi 1,6 persen. ${ }^{34}$ 
Asupan cairan yang cukup diperlukan untuk menstabilkan kembali tekanan darah dan denyut nadi yang meningkat setelah berolahraga. Penelitian tentang pemberian cairan rehidrasi menunjukkan bahwa air mineral memberikan hasil peningkatan denyut nadi yang kecil yaitu sebesar 28 kali per menit. Pemberian cairan elektrolit meningkatkan denyut nadi sebesar 39 kali per menit. Pemberian cairan rehidrasi berupa elektrolit dan glukosa dapat meminimalkan peningkatan tekanan darah diastol setelah berolahraga. ${ }^{27}$

\section{SIMPULAN DAN SARAN}

\section{Simpulan}

Asupan cairan dan status hidrasi dengan pemantauan perubahan berat badan dan persen perubahan berat badan subyek saat sebelum dan sesudah latihan berpengaruh signifikan terhadap tekanan darah sistol $(P<0,05)$. Arah hubungan tersebut adalah setiap kenaikan asupan cairan dan perubahan berat badan menurunkan tekanan darah sistol sebesar 0,408 $\mathrm{mmHg}$. Setiap kenaikan asupan cairan dan perubahan persen berat badan menaikan tekanan darah sebesar $2,762 \mathrm{mmHg}$. Asupan cairan sebagai pengembali status dehidrasi atlet akibat cairan yang hilang karena aktivitas menjadi kunci penting untuk menstabilkan kembali tekanan darah sistol. Semakin sering atlet latihan, semakin sering terpapar kondisi dehidrasi, maka tekanan darah sistol atlet akan terus meningkat.

\section{Saran}

Rehidrasi bagi atlet yang mengalami penurunan berat badan lebih dari 2 persen harus segera dilakukan pasca latihan, di mana kehilangan $1 \mathrm{~kg}$ berat badan dapat diganti dengan $1 \mathrm{~L}$ cairan. Hal ini penting dilakukan untuk menggantikan cairan yang hilang. Pengembangan penelitian selanjutnya dapat melihat hubungan status hidrasi sebelum latihan apakah berhubungan dengan kehilangan berat badan saat latihan, untuk melihat hubungan status hidrasi sebelum dan sesudah latihan.

\section{UCAPAN TERIMA KASIH}

Peneliti mengucapkan terima kasih kepada pemberi bantuan dana penelitian melalui Hibah Penelitian Disertasi, Fakultas Kedokteran UGM
2016 dan seluruh asisten peneliti yang terlibat dalam proses pengambilan data.

\section{RUJUKAN}

1. Wilson $T$ \& Temple NJ. Beverages in Nutrition and Health 1st ed. T. Wilson \& N. J. Temple, eds., New Jersey: Humana Press, 2004.

2. Smolin LA, \& Grosvenor MB. Healthy Eating a Guide to Nutrition. Nutrition for Sport and Exercise. Second Ed. New York: Chelsea House, 2010.

3. David Berton and Hayley A. Young. Do Small Differences in Hydration Status Affect Mood and Mental Performance? Nutr Rev; 73(S2):83-96.

4. Judy A Driskell and Ira Wolinsky. Nutritional Assessment of Athletes, Second Edition. London: Taylor and Francis Group, 2011.

5. Alonso, Gonzalez; Jose; Rodriguez, Ricardo Mora; Below, Paul R; Coyle, Edward F. Dehydration Markedly Impairs Cardiovascular Function in Hyperthermic Endurance Athletes during Exercise. American Physiological Society 1997; 01617567/97.

6. Shirreffs SM, Aragon-Vargas LF, Chamorro M, Maughan RJ, Serratosa L, \& Zachwieja JJ. The Sweating Response of Elite Professional Soccer Players to Training in the Heat. Int J Sports Med 2005; 26: 90-95.

7. Glace B, Murphy C, \& McHugh M. Food and Fluid Intake and Disturbances in Gastrointestinal and Mental Function During an Ultramarathon. Int J Sport Nutr and Exerc Metabolism 2002; 12: 414-427.

8. Maughan RJ, Shirreffs SM, Merson SJ, \& Horswill CA. Fluid and Electrolyte Balance in Elite Male Football (Soccer) Players Training in A Cool Environment. Journal of Sport Science 2005; 23(1), DOI:10.1080/02640410410001730115.

9. John E Hall and Guyton, Arthur C. Guyton and Hall Textbook of Medical Physiology Twelfth Edition. USA, Saunders Elsevier, 2011.

10. Sawka, Michael N., Louise M. Burke, E. Randy Eichner, Ronald J. Maughan, Scott J. Montain, Nina S. Stachenfeld. American College of Sports Medicine Position Stand: Exercise and Fluid Replacement. American College of Sports Medicine; 2007. 
11. Greenwood M, Kalman DS, Antonio J. Nutritional Supplements in Sports and Exercise. Greenwood M, Kalman DS, Antonio J, editors. USA: Humana; 2008.

12. Al-Masri L \& Bartlett S. 100 Questions \& Answers about Sports Nutrition and Exercise. Sudbury Massachusetts: Jones and Bartlett Publishers; 2011.

13. Dunford M \& Doyle JA. Nutrition for Sport and Exercise A practical Guide [Internet]. First. West Sussex UK: Wiey - Blackwell; 2012. 265 p. Available from: www.wiley.com/go/daries/nutrition

14. Maughan RJ, editor. Nutrition in Sport Volume VII of the Encyclopedia of Sports Medicine an IOC Medical Commicion Publication. Science. Oxford: Blackwell Science; 2000.

15. Maughan, RJ. Fundamental of Sports Nutrition: Application to Sports Drinks. In R. J. Maughan\& R. Murray, eds. Sport Drinks. Boca Raton, Florida: CRC Press; 2001.

16. Reilly T dkk. Physiology of Sports 1st ed. T Reilly et al., eds., United Kingdom: Taylor and Francis Group; 1990.

17. Persatuan Sepakbola Seluruh Indonesia. Identifikasi Somatotype, Komposisi Tubuh, Asupan Cairan dan Makanan serta Profil Urin Altet Timnas Indonesia U-19. PSSI; 2014

18. Maughan RJ, Watson P, Evans GH, Broad $N$, Shirreffs S. Water Balance and Salt Lossess in Competitive Football. Int. J Nutr. Exerc. Metab 2007. 17,583-594.

19. Arnaoutis, G., dkk. Ad Libitum Fluid Intake Does Not Prevent Dehydration in Suboptimally Hydrated Young Soccer Players During Training Session of Summper Camp. Int. J. Sport. Nutr. Exec. Melab. 2012. 23(3):245-51.

20. Fillah Fithra Dieny dan Dittasari Putriana. Status Hidrasi Sebelum dan Sesudah Latihan Atlet Sepakbola Remaja. Gizi Indon; 2015; 3(2):86-93.

21. Gordon, RE dkk. Hydration status and fluid intake of urban, underprivileged South African male adolescent soccer players during training. JISSN; 2015. 12:21.

22. Mielgo-ayuso, Juan dkk. Evaluation of nutritional status and energy expenditure in athletes. Nutr Hosp 31 (Supl.3) 2015: 227236.

23. Cleary, Michelle A. Hydration Behaviors Before and After an Educational and Prescribed Hydration Intervention in Adolescent Athletes. Journal of Athletic Training 2012. 47(3):273-28.1.

24. Castro-Sepúlveda, Mauricio dkk. Hydration status after exercise affect resting metabolic rate and heart rate variability. Nutr Hosp 2015: 31(3): 1273-1277.

25. Judelson DA, Maresh CM, Anderson JM, Armstrong LE, Casa DJ, Kramer WJ, et al. Hydration and muscular performance: does fluid balance affect power and high-intensity endurance? Sports Med. 2007;37(10):9072.1

26. William M. Nutrition for Health, Fitness and Sport 8th ed., New York: Mc. Graw-Hill; 2007.

27. Krisnawati D, Pradigdo SF, Kartini A. Efek Cairan Rehidrasi terhadap Denyut Nadi, Tekanan Darah, dan Lama Periode Pemulihan. JMIKI. 2011; 2:133-138.

28. Kathryn L Beck, Jasmine S Thomson, Richard J Swift and Pamela R Von Hurst. Role of Nutrition in Performance Enhancement and Postexercise Recovery. J Sport Sci Med; 2015:6 259-267.

29. Eric DB. Dehydration and Endurance Performance In Competitive Athletes. Nutr Rev; 70(Suppl.2):S132-S136.

30. Laitano, Orlando. Hydration on Science and Strategies in Football. Sport Science Exchange. 2014; 27(128):1-7.

31. Pfeiffer, Ronald $P$ and Mangus, Brent C. 2. Concept of Athletic Training. USA: Jones \& Barlett Learning, 2007.

32. Casa dkk. National Athletic Trainers' Association Position Statement: Fluid Replacement for Athletes. Journal of Athletic Training 2000. 35 (2): 212-224.

33. Coyle, Edward F. Fluid and fel intake during exercise. Journal of Sports Science. 2004; 22:39-55.

34. Da Silva dkk. Pre-fame Hydration Status, Sweat Loss, and Fluid Intake in Elite Brazilian Young Male Soccer Players During Competition. J. Sport Sci. 2012. 30(1):37-42. 